\title{
Selenium and Vitamin E Improve the In Vitro Maturation, Fertilization and Culture to Blastocyst of Porcine Oocytes
}

\author{
K. M. A. TAREQ ${ }^{1,2)}$, Quzi Sharmin AKTER ${ }^{2)}$, M. A. M. Yahia KHANDOKER ${ }^{3)}$ and \\ Hirotada TSUJII) \\ 1) Laboratory of Animal Biotechnology, Department of Bioscience and Biotechnology, Faculty of Agriculture, Shinshu \\ University, Nagano 399-4598, Japan \\ 2) Faculty of Animal Science and Veterinary Medicine, Patuakhali Science and Technology University, Barisal-8210, \\ Bangladesh \\ 3) Department of Animal Breeding and Genetics, Faculty of Animal Husbandry, Bangladesh Agricultural University, \\ Mymensingh-2202, Bangladesh
}

\begin{abstract}
Selenium (Se) and vitamin E (Vit-E), as integral parts of antioxidant systems, play important roles for sperm and embryos in vitro. In this study, the effects of Se and Vit-E on the maturation, in vitro fertilization and culture to blastocysts of porcine oocytes and accumulation of ammonia in the culture medium during different development stages were investigated. The maturation was performed in modified tissue culture medium (mTCM)-199 supplemented with 10\% (v/v) porcine follicular fluid, the fertilization medium was modified Tyrode's albumin lactate pyruvate (mTALP), and the embryo culture medium was modified North Carolina State University (mNCSU)-23. Se in the form of sodium selenite (SS) and seleonL-methionine (SeMet) and Vit-E at different concentrations were also used. The incorporation and oxidation of ${ }^{14} \mathrm{C}(\mathrm{U})$ glucose were assessed with a liquid scintillation counter. In this study, SeMet and SeMet+Vit-E increased oocyte maturation, fertilization and incorporation and oxidation of ${ }^{14} \mathrm{C}(\mathrm{U})$-glucose significantly $(\mathrm{P}<0.05)$ compared with the control and other treatments. In addition, embryo development, specifically in terms of the numbers of morulae and blastocysts, significantly increased $(\mathrm{P}<0.05)$ with SeMet and SeMet+Vit-E. In contrast, the accumulation of ammonia was reduced with SeMet and SeMet+Vit-E compared with other treatments. These findings indicate that SeMet and SeMet+Vit-E may play important roles in reducing the accumulation of ammonia and subsequently in increasing the rate of maturation of porcine oocytes and fertilization, as well as development of the blastocyst and utilization of glucose in in vitro maturation, fertilization and culture to blastocysts of porcine oocytes.
\end{abstract}

Key words: Ammonia, Incorporation and oxidation, Porcine embryo, Selenium, Vitamin E

(J. Reprod. Dev. 58: 621-628, 2012)

A mmonia produced from amino acids present in culture medium inhibits cell growth in vitro. The levels of ammonia increase significantly during the culture period because of the deamination and spontaneous breakdown of amino acids, especially glutamine, in in vitro fertilization of porcine oocytes [1]. The toxic effect of glutamine can be avoided by making use of the fact that dipeptides can be directly used by mammalian cells in vitro [2]. We reported previously that the accumulation of ammonia in the medium can be reduced by supplementation with the dipeptides L-alanyl-L-glutamine and L-glycyl-L-glutamine, which can play important roles in motility and the acrosome reaction (AR) in porcine spermatozoa [3].

In recent years, the involvement of free radicals and oxidative damage has been proposed as an alternate mechanism for ammonia toxicity [4]. Selenium (Se), an essential trace element for mammals, is an integral part of antioxidant systems [5]. Se-dependent glutathione peroxidase (GPx) has an important role in free radical

Received: March 31, 2012

Accepted: May 9, 2012

Published online in J-STAGE: June 05, 2012

(C)2012 by the Society for Reproduction and Development

Correspondence: H Tsujii (e-mail: htsujii@shinshu-u.ac.jp) protective mechanisms. Se may have a role in the motility of bovine spermatozoa by protecting them from oxidative damage [6]. Se, which commonly replaces sulfur in proteins, is normally incorporated through selenoamino acids (L-selenomethionine, L-selenocysteine) and selenoenzymes, such as GPxs, which oxidize glutathione in the antioxidant system and protect cells from oxidative damage [7].

Vitamin E (Vit-E) is one of the most important antioxidative molecules, residing mainly in the cell membranes [8]. We reported previously that antioxidant Vit-E protects mouse embryos from oxidative damage [9]. Olson and Seidel [10] reported that the development of bovine embryos in vitro improved with Vit-E addition. We previous reported that seleon-L-methionine (SeMet) and SeMet+Vit-E may play important roles in reducing the accumulation of ammonia and subsequently in increasing the rate of AR and the utilization of glucose in porcine spermatozoa [11].

Although several studies have shown the importance of Se levels in embryo development, the direct influences of Se and Vit-E on reducing the accumulation of ammonia and on embryo development in porcine in vitro have not been definitively demonstrated yet.

In this study, we have investigated the roles of sodium selenite (SS), SeMet and Vit-E in embryo development and accumulation of ammonia in the medium during in vitro maturation, fertilization 
and embryo development in porcine and assessed the utilization of ${ }^{14} \mathrm{C}(\mathrm{U})$-glucose.

\section{Materials and Methods}

\section{Chemicals}

Radioactive ${ }^{14} \mathrm{C}(\mathrm{U})$-glucose was purchased from American Radiolabeled Chemicals (St. Louis, MO, USA); SS, SeMet,Vit-E ( $\alpha$-tocopheryl acetate, E) and all other chemicals were of analytical grade and purchased from Nacalai Tesque (Kyoto, Japan), unless otherwise indicated. Vit-E was dissolved in ethanol, and an emulsion was formed by vortex mixing before being adding it to the embryo. The final concentration of ethanol was $<2 \%$ (the volume of ethanol was $0.15 \mathrm{ml}$ in the total volume) [12]. The control and other treatments involved an equivalent amount of ethanol.

\section{Oocyte recovery and in vitro maturation}

Ovaries were collected from gilts (Landrace, Large White and Duroc) at a local slaughterhouse and transported to the laboratory in physiological saline supplemented with $100 \mathrm{U} / \mathrm{ml}$ penicillin $\mathrm{G}$ and $100 \mathrm{mg} / \mathrm{ml}$ streptomycin sulfate at around 30-35 C within 1-3 h of collection. Cumulus-oocyte complexes (COCs) from follicles 3 to 6 $\mathrm{mm}$ in diameter were aspirated using an 18-gauge needle attached to a $10 \mathrm{ml}$ disposable syringe. Intact COCs were selected using mouth pipettes and washed three times in HEPES-buffered North Caroline State University medium (NCSU)-23 supplemented with $0.3 \%$ bovine serum albumin (BSA). Washed COCs were transferred to IVM medium consisting of modified tissue culture medium (mTCM)-199, which was supplemented with $10 \mathrm{ng} / \mathrm{ml}$ epidermal growth factor, $4 \mathrm{IU} / \mathrm{ml}$ pregnant mare serum gonadotropin (PMSG; Sankyo Zoki, Tokyo, Japan) and human chronic gonadotropin (hCG; Sankyo Zoki), and $10 \%(\mathrm{v} / \mathrm{v})$ porcine follicular fluid $(\mathrm{pFF})$. The $\mathrm{pFF}$ was collected from antral follicles of prepubescent gilts, centrifuged at $1600 \times \mathrm{g}$ for 30 min and filtered through 1.2 and $0.45-\mu \mathrm{m}$ syringe filters (Toyo Roshi Kaisha, Tokyo, Japan). The filtered $\mathrm{pFF}$ was stored in aliquots at -20 C. Fifty COCs in $500 \mu \mathrm{l}$ of IVM medium were cultured at $39 \mathrm{C}$ in $5 \% \mathrm{CO}_{2}$ in air. After culturing for $22 \mathrm{~h}$, COCs were washed three times and cultured in PMSG and hCG-free mTCM-199 medium for an additional $22 \mathrm{~h}$ at $39 \mathrm{C}$ in $5 \% \mathrm{CO}_{2}$ in air.

\section{Sperm preparation and in vitro fertilization}

Ejaculated sperm were obtained from Duroc boars and diluted according to the method of Johnson et al. [13]. After being washed three times by centrifugation at $900 \times g$ for $5 \mathrm{~min}$, the sperm pellet was resuspended in in vitro fertilization medium, which was modified Tyrode's albumin lactate pyruvate (mTALP) medium containing $3 \mathrm{mg} / \mathrm{mL}$ BSA and $2 \mathrm{mM}$ caffeine, mTALP medium, to give a final concentration of $2 \times 10^{6}$ spermatozoa $/ \mathrm{ml}$ [1]. The oocytes and spermatozoa were co-cultured for $6 \mathrm{~h}$ at $39 \mathrm{C}$ in an atmosphere of $5 \% \mathrm{CO}_{2}$ in air. At $44 \mathrm{~h}$ of maturation culture, oocytes were freed from cumulus cells by repeated pipetting in $0.1 \%$ hyaluronidase in mTCM-199 medium and washed three times with pre-equilibrated mTALP. After washing, 20-25 oocytes were placed in $45 \mu \mathrm{l}$ drops of the MTALP (fertilizing drop) covered with pre-warmed paraffin oil and $5 \mu \mathrm{l}$ of sperm suspension was added to each fertilization drop to give a final sperm concentration of $2 \times 10^{6} \mathrm{sperm} / \mathrm{ml}$. After co-incubation of gametes for $6 \mathrm{~h}$, the presumptive zygotes were washed and transferred into in vitro culture (IVC) medium.

\section{Embryo culture}

After IVF, COCs were washed several times in a fertilization drop to remove spermatozoa loosely attached to inseminated oocytes and then washed a final time in glucose-free mNCSU-23 [14] medium containing $0.5 \mathrm{mM}$ sodium pyruvate, $5 \mathrm{mM}$ sodium lactate, and $0.4 \%$ BSA (A-6003, fraction V). Ten to fifteen putative zygotes were then freed from cumulus cells and transferred to a 30- $\mu 1$ microdrop of culture medium covered with warm mineral oil. Embryos were cultured up to $168 \mathrm{~h}$ after IVF in a humidified atmosphere of $39 \mathrm{C}$ and $5 \% \mathrm{CO}_{2}$ in air without any replacement with fresh medium [15].

\section{Assessment of meiotic maturation, sperm penetration and embryo cell number}

Oocyte maturation, fertilization, cleavage and blastocyst formation and blastomere number in blastocysts were examined at $44 \mathrm{~h}$ after IVM and at 12, 48 and $168 \mathrm{~h}$ after IVF, respectively. Oocytes or blastocysts at the time of examination were mounted on a glass slide and fixed for $10 \mathrm{~min}$ in $25 \%$ (v/v) acetic acid in ethanol. Fixation was carried out on a 33.8 C warm plate for the removal of lipids within $10 \mathrm{~min}$. They were then stained with $1 \%(\mathrm{w} / \mathrm{v})$ orcein in $45 \%(\mathrm{v} / \mathrm{v})$ acetic acid solution and examined under a phase-contrast microscope (IX-50, Olympus, Tokyo, Japan) at 400×. Meiotic stage of the oocytes was assessed according to Hunter and Polge [16]. Oocytes at the metaphase-II (MII) stage were regarded as mature. Oocytes were considered to be penetrated when they had one or more swollen sperm heads or male pronuclei with corresponding sperm tails.

\section{Differential staining}

The quality of blastocysts was assessed by differential staining of the inner cell mass (ICM) and trophectoderm (TE) cells according to the modified staining procedure of Thouas et al. [17]. Briefly, hatched blastocysts were used without treatment, and unhatched blastocysts were treated with $0.25 \%$ pronase (w/v, Sigma-Aldrich, St. Louis, MO, USA) for $5 \mathrm{~min}$ to dissolve the zonae pellucidae. After rinsing in mNCSU-23 medium, zona-free blastocysts were stained with $0.01 \%(\mathrm{w} / \mathrm{v})$ bisbenzimide for $1 \mathrm{~h}$. The blastocysts were rinsed in mNCSU-23 medium again and treated with $0.04 \%$ (v/v) Triton X-100 (Sigma-Aldrich) for $3 \mathrm{~min}$ followed by treatment with $0.005 \%$ $(\mathrm{w} / \mathrm{v})$ propidium iodide (Sigma-Aldrich) for $10 \mathrm{~min}$. After another rinse in mNCSU-23 medium, stained blastocysts were mounted on glass slides under a cover slip and examined under an inverted microscope (Nikon, Tokyo, Japan) equipped with epifluorescence. The ICM nuclei labeled with bisbenzimide appeared blue, and the TE cell nuclei labeled with both bisbenzimide and propidium iodide appeared pink. Any blastocysts without dual staining were excluded from the study [17].

\section{Incorporation and oxidation of radiolabeled glucose by porcine} oocytes

The radioactive substrates, ${ }^{14} \mathrm{C}(\mathrm{U})$-glucose (specific activity: $185 \mathrm{MBq} / \mathrm{mmol}$ ), was as described in our previous study [18]. Briefly, each of the five oocytes and embryos at a particular stage of development was transferred into a $100-\mu 1$ drop of the culture 
medium containing $18.5 \mathrm{kBq}^{14} \mathrm{C}(\mathrm{U})$-glucose and then overlaid with mineral oil. ${ }^{14} \mathrm{C}(\mathrm{U})$-glucose was incorporated into a sodium pyruvate, sodium lactate and glucose-free medium containing oocytes at the MII stage at $44 \mathrm{~h}$ after culture of oocytes, cleaved oocytes at the 2-cell stage at $48 \mathrm{~h}$ and blastocysts at $168 \mathrm{~h}$ after IVF. On the other hand, $1 \mathrm{ml}$ of $2.5 \mathrm{mM} \mathrm{NaOH}$ solution was transferred into a $1.5 \mathrm{ml}$ microtube as a trap for the evolved ${ }^{14} \mathrm{C}(\mathrm{U})-\mathrm{CO}_{2}$. Microtubes of both $\mathrm{NaOH}$ and ${ }^{14} \mathrm{C}(\mathrm{U})$-glucose containing oocytes at the maturation, fertilization, cleavage and blastocyst stages were confined in a scintillation vial using a rubber stopper. The scintillation vials were incubated for 0 to $3 \mathrm{~h}$ in a cell culture incubator with a humidified atmosphere of $5 \% \mathrm{CO}_{2}$ in air at $39 \mathrm{C}$. Just after completion of the specific incubation period, the metabolic reactions of oocytes and embryos were stopped with an injection of $100 \mu$ of $10 \%$ perchloric acid (PCA) for glucose kept at room temperature for $24 \mathrm{~h}$. The acid-insoluble materials were carefully washed by filtration (8.0 $\mu \mathrm{M}$ white SCWP, $47 \mathrm{~mm}$; Millipore, Bedford, MA, USA) with $5 \%$ PCA or TCA, and the filter papers were kept overnight under a lamp. After drying, the filter papers were transferred into scintillation vials. The $\mathrm{NaOH}$ solution was transferred into a new scintillation vial by washing $3-4$ times with cocktail $(0.5 \%$ PPO $+0.03 \%$ POPOP solution in toluene). All the scintillation vials plus three blanks for each group with $5 \mathrm{ml}$ of cocktail were set in a liquid scintillation counter (LS-6500, Beckman-Coulter, Brea, CA, USA) to determine the levels of radioactivity. This experiment was conducted five times to improve its accuracy. The values of incorporation and oxidation are expressed directly as counts per minute (cpm) [9].

\section{Ammonia assay}

The ammonia concentrations in the medium were assessed using the Berthelot-indophenol method as described in our previous study [19]. This method was further used to analyze the maturation at the MII stage within $44 \mathrm{~h}$, fertilization for $6 \mathrm{~h}$ and culture of oocytes, cleavage to the 2-cell stage at $48 \mathrm{~h}$ and then the blastocyst stage at $168 \mathrm{~h}$. After completion of the stages mentioned above, $50 \mu \mathrm{l}$ of the culture medium was taken out immediately to measure the concentration of ammonia. This procedure was performed five times for each analysis. A calibration curve in the range of $0-0.40$ $\mathrm{mM}$ ammonia was run with each experiment. The mean correlation coefficient for the calibration curves of five experiments was 0.994 .

\section{Experimental design}

In the first experiment, maturation was performed for $44 \mathrm{~h}$ to find out the optimal additive concentration of SS, SeMet, and Vit-E in medium mTCM-199 (0, 0.5, 5 and $10 \mu \mathrm{g} / 1$ and $0,0.5,1.0$ and 2.0 $\mathrm{mM}$ ). In the second experiment, the various combinations of the optimal concentration of SS, SeMet, and Vit-E were used to show the effect of mTCM-199 on IVM for $44 \mathrm{~h}$, the effect of mTALP on IVF for $6 \mathrm{~h}$ and the effect of mNCSU-23 on IVC for $168 \mathrm{~h}$ respectively. Finally, the incorporation and oxidation of the ${ }^{14} \mathrm{C}(\mathrm{U})$-glucose, accumulation of ammonia after IVM, IVF and IVC and the number of cells of blastocysts were investigated. After supplementation of all the chemicals, the pHs (HM-30s, Tokyo TOA Electronics, Tokyo, Japan) and osmolarities (Model 3300, Advanced Instruments, Norwood, MA, USA) of these media were adjusted to 7.4 with 1 $\mathrm{NHCl}$ or $1 \mathrm{~N} \mathrm{NaOH}$ and $270 \mathrm{mOsm}$ with $\mathrm{NaCl}$, respectively.

\section{Statistical analysis}

In each experimental group, oocytes were randomly distributed. Each experiment was repeated five times. All data were subjected to one-way ANOVA followed by Tukey's test to determine differences among experimental groups using GraphPad Version 4.0 [20]. Statistical significance was determined when a $P$ value was less than 0.05 .

\section{Results}

Figure 1 shows effects of sodium selenite (SS), seleon-L-methionine (SeMet) and vitamin E (Vit-E) on metaphase II development in porcine oocytes. It is clear from the figure that $5 \mu \mathrm{g} / \mathrm{l}$ of the supplements of SS and SeMet was significantly more effective $(\mathrm{P}<0.05)$ for MII development than the control and other two concentrations $(0.5$ and $10 \mu \mathrm{g} / \mathrm{l})$. In the case of Vit-E, $1.0 \mathrm{mM}$ was significantly more effective $(\mathrm{P}<0.05)$ than the control and other two concentrations (0.5 and $2.0 \mathrm{mM})$.

Table 1 presents the effect of SS, SeMet, Vit-E and their combinations on the percentages of maturation and fertilization of porcine oocytes. This table accumulated the concentrations $(5 \mu \mathrm{g} / 1,1.0 \mathrm{mM}$ and their combination) found to be more effective in Fig. 1. The percentages of development to the MII stage, monospermic fertilization and male pronuclear formation significantly increased $(\mathrm{P}<0.05)$ when oocytes were treated with SeMet and SeMet+Vit-E compared with the control and other treatments. However, there was no significant difference among SS, Vit-E, SS+Vit-E and SS+SeMet+Vit-E in terms of maturation and fertilization.

The rates of incorporation and oxidation of ${ }^{14} \mathrm{C}(\mathrm{U})$-glucose and the accumulation of ammonia upon treatment with SS, SeMet, Vit-E and their combinations for maturation and fertilization of porcine oocytes are shown in Table 2. The incorporation and oxidation rates of ${ }^{14} \mathrm{C}(\mathrm{U})$-glucose were significantly higher $(\mathrm{P}<0.05)$ in oocytes treated with SeMet, SeMet+Vit-E and SS+SeMet+Vit-E compared with those of the control during maturation and fertilization $(\mathrm{P}<0.05)$.

The accumulation of ammonia in the medium was significantly reduced $(\mathrm{P}<0.05)$ after the addition of SeMet and SeMet+Vit-E, with the exceptions of SS, Vit-E and SS+SeMet+Vit-E, compared with the other treatments during maturation and fertilization.

The effects of SS, SeMet, Vit-E and their combinations on the development of embryos in terms of percentages of porcine IVC are shown in Table 3. The development ratios for the 2-cell, morula and blastocyst stages were higher with SeMet and SeMet+Vit-E. In the presence of SS, Vit-E and SS+SeMet+Vit-E, no differences $(\mathrm{P}<0.05)$ were observed at the 2-cell, morula and blastocyst stages compared with the control after IVF.

The rates of incorporation and oxidation of ${ }^{14} \mathrm{C}(\mathrm{U})$-glucose and the accumulation of ammonia upon treatment with SS, SeMet, Vit-E and their combinations in medium for the 2-cell and blastocyst stages are shown in Table 4. The incorporation and oxidation rates of ${ }^{14} \mathrm{C}$ (U)-glucose were higher $(\mathrm{P}<0.05)$ in embryos treated with SeMet and SeMet+Vit-E at the 2-cell and blastocyst stages compared with those of the control. The accumulation of ammonia in the culture medium was significantly reduced $(\mathrm{P}<0.05)$ in the presence of SeMet and SeMet+Vit-E compared with those of the other treatments.

The effects of SS, SeMet, Vit-E and their combinations on blastocyst 


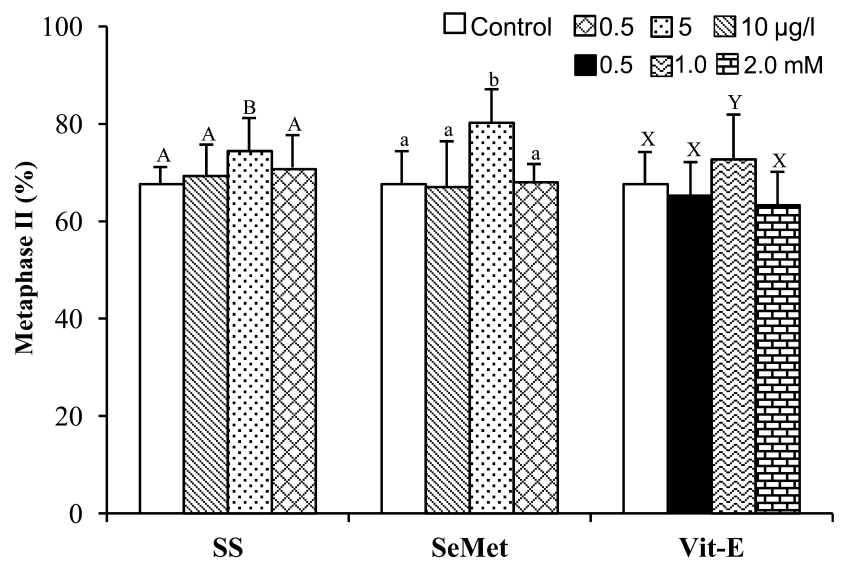

Fig. 1. Effects of sodium selenite (SS), seleon-L-methionine (SeMet) and vitamin $\mathrm{E}$ (Vit-E) on metaphase II in porcine oocytes. Different letters indicate significant differences $(\mathrm{P}<0.05)$ among the treatments at the different concentrations.

cell number are shown in Table 5. The ICM and TE cell numbers were taken into consideration. The numbers of ICM cells for SeMet and SeMet+Vit-E were significantly higher $(\mathrm{P}<0.05)$ than for the control. In addition, more TE cells were observed for SeMet and SeMet+Vit-E in comparison with the control and all other treatments.

\section{Discussion}

Oocyte growth and maturation appear to be affected by nutritional imbalances, hormonal disturbances, and physical conditions of the microenvironment, such as oxidative stress [21-23]. Oxygen concentration is higher in in vitro cultures than in in vivo conditions, and free radicals are produced during aerobic metabolism of cells [24-26]. The oxidative modification of cell components due to the action of reactive oxygen species (ROS) is one of the most potentially damaging processes for proper cell function and may lead to cell death by necrosis or apoptosis [27, 28]. During IVM of oocytes, ROS are produced [29-31], and it has been shown that cumulus cells play a major role in the antioxidant defense of oocytes using GPx and catalase activities. Since these enzymes are active in mature oocytes, it seems that oocytes also have their own capacity to control ROS production during maturation by their antioxidant system [29-31]. Basini and Tamanini [32] showed that Se stimulated proliferation of bovine granulosa cells and had some stimulatory effects on estradiol secretion. In this study, the effect of the antioxidation was seen during in vitro maturation of oocytes,

Table 1. Effect of sodium selenite (SS), seleon-L-methionine (SeMet), vitamin E (Vit-E) and their combinations on the percentages of maturation and fertilization of porcine oocytes

\begin{tabular}{|c|c|c|c|c|c|c|c|}
\hline \multirow[b]{2}{*}{ Treatment } & \multicolumn{3}{|c|}{ Maturation (\%) } & \multicolumn{4}{|c|}{ Fertilization (\%) } \\
\hline & $\mathrm{n}$ & $\begin{array}{l}\text { Germinal } \\
\text { vesicle }^{\mathrm{a}}\end{array}$ & $\begin{array}{l}\text { Metaphase } \\
\text { II }^{\mathrm{b}}\end{array}$ & $\mathrm{n}$ & Penetration $^{\mathrm{a}}$ & $\begin{array}{l}\text { Monospermic } \\
\text { fertilization }^{\mathrm{b}}\end{array}$ & $\mathrm{MPN}^{\mathrm{c}, \mathrm{b}}$ \\
\hline Control (0) & 325 & $13.0 \pm 4.0$ & $67.6 \pm 3.7^{\mathrm{a}}$ & 285 & $67.0 \pm 5.0^{\mathrm{a}}$ & $53.4 \pm 4.0^{\mathrm{a}}$ & $47.1 \pm 1.7^{\mathrm{a}}$ \\
\hline $\mathrm{SS}(5 \mu \mathrm{g} / \mathrm{l})$ & 316 & $12.7 \pm 2.1$ & $74.4 \pm 3.5^{\mathrm{a}}$ & 272 & $56.9 \pm 2.0^{\mathrm{a}}$ & $58.7 \pm 6.1^{\mathrm{a}}$ & $41.9 \pm 5.3^{\mathrm{a}}$ \\
\hline SeMet $(5 \mu \mathrm{g} / 1)$ & 304 & $5.6 \pm 2.1$ & $80.2 \pm 2.1^{b}$ & 298 & $59.0 \pm 4.0^{\mathrm{a}}$ & $65.3 \pm 1.5^{\mathrm{b}}$ & $73.3 \pm 3.1^{\mathrm{b}}$ \\
\hline Vit-E (1.0 mM) & 333 & $12.1 \pm 2.0$ & $72.2 \pm 2.0^{\mathrm{a}}$ & 222 & $62.1 \pm 2.0^{\mathrm{a}}$ & $52.2 \pm 2.1^{\mathrm{a}}$ & $53.6 \pm 3.5^{\mathrm{a}}$ \\
\hline SeMet+Vit-E $(5 \mu \mathrm{g} / 1+1.0 \mathrm{mM})$ & 302 & $7.1 \pm 1.5$ & $85.1 \pm 4.2^{\mathrm{c}}$ & 235 & $74.8 \pm 5.0^{\mathrm{b}}$ & $70.4 \pm 3.2^{\mathrm{c}}$ & $75.0 \pm 3.1^{\mathrm{b}}$ \\
\hline $\mathrm{SS}+\mathrm{Vit}-\mathrm{E}(5 \mu \mathrm{g} / \mathrm{l}+1.0 \mathrm{mM})$ & 295 & $10.2 \pm 1.5$ & $76.1 \pm 4.5^{\mathrm{a}}$ & 255 & $65.0 \pm 5.0^{\mathrm{a}}$ & $59.6 \pm 3.5^{\mathrm{a}}$ & $60.2 \pm 6.1^{\mathrm{c}}$ \\
\hline SS+SeMet+Vit-E $(5 \mu \mathrm{g} / 1+5 \mu \mathrm{g} / 1+1.0 \mathrm{mM})$ & 310 & $9.0 \pm 2.0$ & $73.5 \pm 2.5^{\mathrm{a}}$ & 245 & $68.1 \pm 3.0^{\mathrm{a}}$ & $44.3 \pm 4.0^{\mathrm{a}}$ & $56.2 \pm 4.0^{\mathrm{d}}$ \\
\hline
\end{tabular}

Within a column, values with different letters $(\mathrm{a}-\mathrm{d})$ are significantly different $(\mathrm{P}<0.05)$. n: number of oocytes, five replicates. ${ }^{\text {a }}$ Percentage of the number of oocytes. ${ }^{b}$ Percentage of the number of penetrated oocytes. ${ }^{\mathrm{c}}$ Male pronuclear formation.

Table 2. The rates of incorporation and oxidation of ${ }^{14} \mathrm{C}(\mathrm{U})$-glucose and the accumulation of ammonia upon treatment with sodium selenite (SS), seleonL-methionine (SeMet), vitamin-E (Vit-E) and their combinations for maturation and fertilization of porcine oocytes

\begin{tabular}{|c|c|c|c|c|c|c|}
\hline \multirow{2}{*}{$\begin{array}{c}\text { Treatment } \\
\mathrm{n}(15)\end{array}$} & \multicolumn{2}{|c|}{$\begin{array}{l}\text { Incorporation }{ }^{14} \mathrm{C}(\mathrm{U}) \text {-glucose } \\
\text { (cpm/oocyte) }\end{array}$} & \multicolumn{2}{|c|}{$\begin{array}{l}\text { Oxidation }{ }^{14} \mathrm{C}(\mathrm{U}) \text {-glucose } \\
\text { (cpm/oocyte) }\end{array}$} & \multicolumn{2}{|c|}{$\begin{array}{l}\text { Ammonia concentration } \\
\qquad\left(\times 10^{-1} \mathrm{mM}\right)\end{array}$} \\
\hline & Maturation $^{\mathrm{a}}$ & Fertilization $^{\mathrm{b}}$ & Maturation $^{\mathrm{a}}$ & Fertilization $^{\mathrm{b}}$ & Maturation $^{\mathrm{a}}$ & Fertilization $^{b}$ \\
\hline Control (0) & $1890.0 \pm 254.6^{\mathrm{a}}$ & $1723.3 \pm 194.7^{\mathrm{a}}$ & $143.7 \pm 11.7^{\mathrm{a}}$ & $140.3 \pm 4.2^{\mathrm{a}}$ & $1.3 \pm 0.1^{\mathrm{a}}$ & $1.8 \pm 0.1^{\mathrm{a}}$ \\
\hline $\mathrm{SS}(5 \mu \mathrm{g} / 1)$ & $2912.0 \pm 32.9^{\mathrm{a}}$ & $3384.3 \pm 159.2^{\mathrm{b}}$ & $174.7 \pm 9.0^{\mathrm{b}}$ & $193.7 \pm 5.5^{\mathrm{a}}$ & $1.3 \pm 0.1^{\mathrm{a}}$ & $1.7 \pm 0.1^{\mathrm{a}}$ \\
\hline SeMet $(5 \mu \mathrm{g} / 1)$ & $6157.3 \pm 334.1^{\mathrm{b}}$ & $7531.0 \pm 102.8^{\mathrm{c}}$ & $226.7 \pm 3.1^{\mathrm{c}}$ & $284.3 \pm 62.9^{b}$ & $1.2 \pm 0.1^{\mathrm{b}}$ & $1.1 \pm 0.1^{\mathrm{b}}$ \\
\hline Vit-E (1.0 mM) & $1627.3 \pm 44.3^{\mathrm{a}}$ & $1856.7 \pm 44.9^{\mathrm{a}}$ & $153.7 \pm 3.5^{\mathrm{a}}$ & $150.3 \pm 4.2^{\mathrm{a}}$ & $1.4 \pm 0.2^{\mathrm{a}}$ & $1.7 \pm 0.4^{\mathrm{a}}$ \\
\hline SeMet+Vit-E $(5 \mu \mathrm{g} / 1+1.0 \mathrm{mM})$ & $8232.3 \pm 980.6^{\mathrm{c}}$ & $9298.0 \pm 427.9^{d}$ & $334.0 \pm 3.1^{\mathrm{d}}$ & $346.3 \pm 31.8^{\mathrm{c}}$ & $1.1 \pm 0.1^{\mathrm{c}}$ & $1.0 \pm 0.2^{\mathrm{b}}$ \\
\hline $\mathrm{SS}+\operatorname{Vit}-\mathrm{E}(5 \mu \mathrm{g} / 1+1.0 \mathrm{mM})$ & $3006.0 \pm 66.0^{\mathrm{a}}$ & $4206.3 \pm 679.8^{\mathrm{e}}$ & $149.3 \pm 7.0^{\mathrm{a}}$ & $258.7 \pm 61.2^{\mathrm{d}}$ & $1.3 \pm 0.1^{\mathrm{a}}$ & $1.6 \pm 0.1^{\mathrm{c}}$ \\
\hline SS+SeMet+Vit-E $(5 \mu \mathrm{g} / 1+5 \mu \mathrm{g} / 1+1.0 \mathrm{mM})$ & $7991.7 \pm 243.7^{\mathrm{d}}$ & $8875.0 \pm 594.0^{\mathrm{d}}$ & $220.3 \pm 53.5^{\mathrm{c}}$ & $262.3 \pm 8.1^{\mathrm{d}}$ & $1.2 \pm 0.1^{\mathrm{b}}$ & $1.8 \pm 0.2^{\mathrm{a}}$ \\
\hline
\end{tabular}

Within a column, values with different letters $(\mathrm{a}-\mathrm{e})$ are significantly different $(\mathrm{P}<0.05)$. n: number of oocytes, five replicates. ${ }^{a}$ Maturation $(44 \mathrm{~h}$ incubation period in IVM). ${ }^{b}$ Fertilization (the incubation period was $6 \mathrm{~h}$ after IVM). Mean \pm SEM obtained from the average of each replicate. 
Table 3. Effect of sodium selenite (SS), seleon-L-methionine (SeMet), vitamin E (Vit-E) and their combinations on the development of embryos

\begin{tabular}{|c|c|c|c|c|c|}
\hline \multirow{2}{*}{ Treatment } & \multirow{2}{*}{$\mathrm{n}$} & \multicolumn{4}{|c|}{ Percentages of embryo development (mean \pm SEM) ${ }^{b}$} \\
\hline & & $2-4$ cells $^{\mathrm{a}}$ & $8-16$ cells $^{\mathrm{a}}$ & Morula $^{\mathrm{a}}$ & Blastocyst ${ }^{\mathrm{a}}$ \\
\hline Control (0) & 275 & (189) $68.7 \pm 1.8^{\mathrm{a}}$ & (109) $57.7 \pm 2.5^{\mathrm{a}}$ & (58) $30.7 \pm 1.4^{\mathrm{a}}$ & (36) $19.0 \pm 2.5^{\mathrm{a}}$ \\
\hline $\mathrm{SS}(5 \mu \mathrm{g} / \mathrm{l})$ & 263 & (186) $70.7 \pm 1.8^{\mathrm{a}}$ & (124) $66.7 \pm 4.4^{\mathrm{a}}$ & (60) $32.3 \pm 0.9^{\mathrm{a}}$ & (38) $20.4 \pm 2.7^{\mathrm{a}}$ \\
\hline SeMet $(5 \mu \mathrm{g} / \mathrm{l})$ & 271 & (204) $75.3 \pm 0.8^{b}$ & (142) $69.6 \pm 3.0^{\mathrm{b}}$ & (77) $37.8 \pm 3.5^{\mathrm{b}}$ & (51) $25.0 \pm 3.1^{\mathrm{b}}$ \\
\hline Vit-E (1.0 mM) & 259 & (187) $72.2 \pm 1.4^{\mathrm{a}}$ & (114) $60.9 \pm 4.3^{\mathrm{a}}$ & (63) $33.7 \pm 2.6^{\mathrm{a}}$ & (26) $13.9 \pm 3.3^{\mathrm{a}}$ \\
\hline SeMet+Vit-E $(5 \mu \mathrm{g} / 1+1.0 \mathrm{mM})$ & 255 & $78.0 \pm 2.9^{b}$ & (141) $70.8 \pm 1.5^{\mathrm{b}}$ & (80) $40.2 \pm 2.0^{\mathrm{b}}$ & (54) $27.1 \pm 1.1^{\mathrm{b}}$ \\
\hline SS+Vit-E $(5 \mu \mathrm{g} / 1+1.0 \mathrm{mM})$ & 295 & (208) $70.5 \pm 1.6^{\mathrm{a}}$ & (134) $64.4 \pm 4.3^{\mathrm{a}}$ & (71) $34.1 \pm 2.0^{\mathrm{a}}$ & (43) $20.7 \pm 2.0^{\mathrm{a}}$ \\
\hline SS+SeMet+Vit-E $(5 \mu \mathrm{g} / \mathrm{l}+5 \mu \mathrm{g} / \mathrm{l}+1.0 \mathrm{mM})$ & 277 & (204) $73.6 \pm 2.1^{\mathrm{a}}$ & (136) $66.7 \pm 2.3^{\mathrm{a}}$ & (73) $35.8 \pm 2.5^{\mathrm{a}}$ & (36) $17.5 \pm 1.1^{\mathrm{a}}$ \\
\hline
\end{tabular}

Within a column, values with different letters $(\mathrm{a}-\mathrm{b})$ are significantly different $(\mathrm{P}<0.05)$. n: number of embryos, five replicates. ${ }^{\mathrm{a}}$ Embryo development calculated from cleaved embryos. ${ }^{b}$ Mean \pm SEM obtained from the average percentages of each replicate.

Table 4. The rates of incorporation and oxidation of ${ }^{14} \mathrm{C}(\mathrm{U})$-glucose and the accumulation of ammonia upon treatment with sodium selenite (SS), seleonL-methionine (SeMet), vitamin E (Vit-E) and their combinations in medium for the 2-cell and blastocyst stages

\begin{tabular}{|c|c|c|c|c|c|c|}
\hline \multirow{3}{*}{$\begin{array}{l}\text { Treatment } \\
\mathrm{n}(15)\end{array}$} & \multicolumn{6}{|c|}{$(\operatorname{mean} \pm \mathrm{SEM})^{\mathrm{a}}$} \\
\hline & \multicolumn{2}{|c|}{$\begin{array}{c}\text { Incorporation }{ }^{14} \mathrm{C}(\mathrm{U}) \text {-glucose } \\
\text { (cpm/oocyte) }\end{array}$} & \multicolumn{2}{|c|}{$\begin{array}{l}\text { Oxidation }{ }^{14} \mathrm{C}(\mathrm{U}) \text {-glucose } \\
\text { (cpm/oocyte) }\end{array}$} & \multicolumn{2}{|c|}{$\begin{array}{l}\text { Ammonia concentration } \\
\qquad\left(\times 10^{-1} \mathrm{mM}\right)\end{array}$} \\
\hline & 2- cell & Blastocyst & 2 - cell & Blastocyst & 2-cell & Blastocyst \\
\hline Control (0) & $982.7 \pm 161.5^{\mathrm{a}}$ & $1410.0 \pm 160.0^{\mathrm{a}}$ & $230.7 \pm 29.5^{\mathrm{a}}$ & $390.0 \pm 10.0^{\mathrm{a}}$ & $1.3 \pm 0.1^{\mathrm{a}}$ & $1.5 \pm 0.2^{\mathrm{a}}$ \\
\hline $\mathrm{SS}(5 \mu \mathrm{g} / \mathrm{l})$ & $1082.0 \pm 95.0^{\mathrm{a}}$ & $2354.0 \pm 200.0^{\mathrm{a}}$ & $323.0 \pm 38.0^{\mathrm{a}}$ & $451.3 \pm 21.0^{\mathrm{a}}$ & $1.4 \pm 0.1^{\mathrm{a}}$ & $1.2 \pm 0.1^{\mathrm{a}}$ \\
\hline SeMet $(5 \mu \mathrm{g} / 1)$ & $2137.0 \pm 135.0^{\mathrm{b}}$ & $3509.7 \pm 197.5^{\mathrm{b}}$ & $475.0 \pm 20.0^{\mathrm{b}}$ & $518.3 \pm 12.6^{\mathrm{b}}$ & $0.9 \pm 0.1^{\mathrm{b}}$ & $1.0 \pm 0.1^{\mathrm{b}}$ \\
\hline Vit-E $(1.0 \mathrm{mM})$ & $1164.0 \pm 119.0^{\mathrm{a}}$ & $2345.0 \pm 213.0^{\mathrm{a}}$ & $242.0 \pm 40.0^{\mathrm{a}}$ & $450.7 \pm 19.5^{\mathrm{a}}$ & $1.2 \pm 0.1^{\mathrm{a}}$ & $1.6 \pm 0.1^{\mathrm{a}}$ \\
\hline SeMet+Vit-E $(5 \mu \mathrm{g} / 1+1.0 \mathrm{mM})$ & $2927.0 \pm 169.0^{\mathrm{c}}$ & $4890.7 \pm 655.5^{\mathrm{c}}$ & $373.0 \pm 70.0^{\mathrm{c}}$ & $540.0 \pm 50.0^{\mathrm{c}}$ & $0.9 \pm 0.1^{\mathrm{c}}$ & $1.1 \pm 0.2^{\mathrm{c}}$ \\
\hline $\mathrm{SS}+\operatorname{Vit}-\mathrm{E}(5 \mu \mathrm{g} / 1+1.0 \mathrm{mM})$ & $1660.0 \pm 140.0^{\mathrm{b}}$ & $2873.7 \pm 332.5^{\mathrm{c}}$ & $289.0 \pm 30.0^{\mathrm{a}}$ & $441.0 \pm 20.0^{\mathrm{a}}$ & $1.2 \pm 0.1^{\mathrm{a}}$ & $1.4 \pm 0.1^{\mathrm{a}}$ \\
\hline $\mathrm{SS}+\mathrm{SeMet}+\mathrm{Vit}-\mathrm{E}(5 \mu \mathrm{g} / \mathrm{l}+5 \mu \mathrm{g} / \mathrm{l}+1.0 \mathrm{mM})$ & $1229.3 \pm 104.5^{\mathrm{a}}$ & $2398.3 \pm 233.5^{\mathrm{a}}$ & $295.0 \pm 40.0^{\mathrm{a}}$ & $487.0 \pm 30.0^{\mathrm{a}}$ & $1.2 \pm 0.1^{\mathrm{a}}$ & $1.5 \pm 0.2^{\mathrm{a}}$ \\
\hline
\end{tabular}

Within a column, values with different letters $(\mathrm{a}-\mathrm{c})$ are significantly different $(\mathrm{P}<0.05)$. $\mathrm{n}$ : number of embryos, five replicates. ${ }^{\mathrm{a}}$ Mean $\pm \mathrm{SEM}$ obtained from the average of each replicate.

Table 5. Effect of sodium selenite (SS), seleon-L-methionine (SeMet), vitamin E (Vit-E) and their combinations on blastocyst cell number

\begin{tabular}{lcccc}
\hline \multirow{2}{*}{\multicolumn{1}{c}{ Treatment }} & \multicolumn{4}{c}{ Cell numbers $($ mean \pm SEM) } \\
\cline { 2 - 5 } & \multicolumn{1}{c}{ ICM } & TE & Total & TE/ICM \\
\hline Control $(0)$ & $9.0 \pm 1.0^{\mathrm{a}}$ & $27.0 \pm 1.6^{\mathrm{a}}$ & $36.1 \pm 2.0^{\mathrm{a}}$ & $2.8 \pm 1.0$ \\
$\mathrm{SS}(5 \mu \mathrm{g} / \mathrm{l})$ & $12.6 \pm 1.5^{\mathrm{a}}$ & $29.0 \pm 1.6^{\mathrm{a}}$ & $41.0 \pm 3.0^{\mathrm{a}}$ & $2.4 \pm 0.4$ \\
SeMet $(5 \mu \mathrm{g} / \mathrm{l})$ & $16.0 \pm 2.0^{\mathrm{b}}$ & $35.0 \pm 3.2^{\mathrm{b}}$ & $51.0 \pm 5.0^{\mathrm{b}}$ & $2.3 \pm 0.1$ \\
Vit-E $(1.0 \mathrm{mM})$ & $11.6 \pm 1.5^{\mathrm{a}}$ & $28.0 \pm 2.4^{\mathrm{a}}$ & $39.0 \pm 4.0^{\mathrm{a}}$ & $2.5 \pm 0.1$ \\
SeMet+Vit-E $(5 \mu \mathrm{g} / 1+1.0 \mathrm{mM})$ & $18.0 \pm 3.0^{\mathrm{b}}$ & $38.0 \pm 1.6^{\mathrm{b}}$ & $54.1 \pm 2.0^{\mathrm{b}}$ & $2.3 \pm 0.1$ \\
$\mathrm{SS}+$ Vit-E $(5 \mu \mathrm{g} / \mathrm{l}+1.0 \mathrm{mM})$ & $10.6 \pm 1.5^{\mathrm{a}}$ & $26.0 \pm 0.8^{\mathrm{a}}$ & $36.0 \pm 2.0^{\mathrm{a}}$ & $2.6 \pm 0.2$ \\
SS+SeMet+Vit-E $(5 \mu \mathrm{g} / 1+5 \mu \mathrm{g} / 1+1.0 \mathrm{mM})$ & $10.0 \pm 2.0^{\mathrm{a}}$ & $25.0 \pm 2.4^{\mathrm{a}}$ & $35.0 \pm 2.0^{\mathrm{a}}$ & $2.7 \pm 0.1$ \\
\hline
\end{tabular}

Values shown were obtained with 15 embryos from three replicates. Within the same column, values with different superscripts letters $(\mathrm{a}-\mathrm{b})$ are significantly different $(\mathrm{P}<0.05)$.

and this was agreement with these previous results. In particular, SeMet and SeMet+Vit-E significantly enhanced the development to the MII stage, monospermic fertilization and male pronuclear formation. Generally, SeMet and other Se compounds are dynamically metabolized into a wide array of products, and these derivatives may directly influence the chemopreventive effects of Se [33, 34]. These compounds might be better precursors for generating methylated $\mathrm{Se}$ intermediates. In general, Se undergoes reductive metabolism and forms methylated excretory products, whereas sulfur tends to form more oxidized excretory products [35]. The optimum concentration of Se and Vit-E used in the present study is similar to the concentration used by porcine embryos and sperm $[12,36]$.

At the time of fertilization, one capacitated spermatozoon binds to the zona pellucida ( $\mathrm{ZP}$ ) and undergoes the acrosome reaction before 
crossing the perivitelline space to reach the plasma membrane of the oocyte. Low levels of ROS play a critical role in induction of sperm capacitation and the AR during fertilization in humans $[37,38]$ and bulls [39]. Moreover, tyrosine phosphorylation of sperm proteins in humans [40] and bulls [39] is in part regulated by ROS and is an essential trigger for the AR after sperm-ZP binding. Although the proper balance between ROS and antioxidants adjusts oxidative stress to the optimal levels in the reproductive tract in vivo [41], addition of tannic acid to IVF medium for the purpose of preventing polyspermy in porcine oocytes has strong ROS scavenging activity [42]. We have found that monospermic fertilization and male pronuclear formation were significantly increased by SeMet and SeMet+Vit-E compared with other treatments (Table 1). Brzezinska-Slebodzinska et al. [43] indicated that Vit-E's role in boar semen was as an antioxidant. Boar spermatozoa contain glutathione peroxidase (GPx) and $\alpha$-tocopherol [44], suggesting that both Se and Vit-E have roles in preventing peroxide damage to sperm cells. Se seems to be involved in the structure of the spermatozoon tail mid piece, the shape, and/or the array of the mitochondria within the coil, as well as contact of the coil with the outer plasma membrane of the tail mid piece [45]. When Se and $\alpha$-tocopherol containing the antioxidant SS were added to bovine semen, spermatozoon motility increased, suggesting that adding $\mathrm{Se}$ to semen extender may enhance spermatozoon function [46].

Uhm et al. [47] showed that the addition of SS to culture media increased the blastocyst rate and cell number, decreased the apoptotic index and increased the expression of GPx in porcine embryos. In our study, the numbers of cells and blastocysts were increased with SeMet and SeMet+Vit-E in comparison with SS. Ebert et al. [48] demonstrated that Se supplementation of bone marrow stromal cell culture media was effective in restoring antioxidative capacity and in reducing cell damage. Se acts via intracellular signaling including protein kinase $\mathrm{C}$, nuclear factor-kappa $\mathrm{B}$ and inhibitors of apoptosis proteins [49]. Many of the biological actions of selenium have been attributed to powerful antioxidant properties, including direct quenching of ROS, chelation of metal ions and regeneration of Se-GPx antioxidants. Yeo and Kang [50] investigated the prevention of cell death by selenium using cultured brain-derived neural progenitor cells (NPCs) and showed that selenite inhibits $\mathrm{H}_{2} \mathrm{O}_{2}$-induced apoptosis of NPCs.

A vast number of studies have been conducted on glucose metabolism in mammalian preimplantation embryos; nutrient uptake studies carried out on porcine embryos have shown that the embryos consume glucose and produce lactate at all stages of development. Therefore, glucose-containing media are commonly used for producing porcine embryos in vitro [51, 52]. The incorporation and oxidation of glucose have become indicators of the vitality of oocytes and eggs $[9,18]$. In this study, the incorporation and oxidation rates of ${ }^{14} \mathrm{C}(\mathrm{U})$-glucose were significantly higher in oocytes treated with SeMet and SeMet+Vit-E than those of the control during maturation and fertilization. Generation of ROS induced by glucose utilization was assumed to be caused by the activation of NADPH oxidase, an enzyme that catalyzes the oxidation of NADPH, which generates NADP that serves as a coenzyme of the oxidative arm of the pentose phosphate pathway (PPP) [53-57]. On the other hand, NADPH generated as a result of the PPP activity is also reported to act for the reduction of intracellular glutathione (GSH), a tripeptide thiol compound that plays a major role in regulating ROS concentrations within cytoplasm [58]. During early development, the embryos seem to be dependent on the stored GSH that may be packaged during oocyte development in the ovary [59]. Gardiner and Reed [60] observed that the GSH content of mouse embryos decreases continuously from the unfertilized oocytes to blastocyst stage. Thus, it is likely that the observed decrease in GSH content could be due to a depletion of GSH stored in the oocytes combined with an inability of the embryo to synthesize GSH $[60,61]$. Therefore, we think that the addition of Se-GPx antioxidants is necessary for culturing embryos in vitro.

Amino acids support normal preimplantation development in vivo as evidenced by studies in vitro. Undergoing, spontaneous degradation, the breakdown of the amino acids results in the formation of pyrrolidone carbonic acid and potentially harmful ammonia. Ammonia toxicity for living cells is well recognized in vitro and in vivo. The increased levels of ammonia decrease the $\mathrm{pH}$ and increase the osmolarity, leading to a progressive loss in sperm motility [62] and decreased rates of porcine oocyte development to the MII stage and monospermic fertilization in vitro [1]. In our previous study, ammonia was added to medium to investigate the effects of Se and Vit-E, and the sperm motility, viability, AR and ammonia accumulation were observed [11]. The results showed that the accumulation of ammonia was reduced by SeMet and SeMet+Vit-E compared with those of the other treatments. We suggest that SeMet and SeMet+Vit-E play important roles in reducing the accumulation of ammonia in culture medium and increase the rates of oocyte maturation, fertilization and development to blastocysts. These results were in agreement with the study of Keskes-Ammar et al. [63], who reported that the combination of Se and Vit-E, in comparison with single supplementation, improves human sperm in vitro. Kosenko et al. [4] suggested ammonia toxicity as an alternate mechanism for the involvement of free radicals and oxidative damage. GPx, GSH and Vit-E (enzymatic and nonenzymatic antioxidant) are involved in reducing ammonia toxicity and the production of free radicals $[64,65]$. We suggested that SeMet and SeMet+Vit-E might protect against the oxidative damage of ammonia.

In conclusion, our present results provide evidence that Se and Vit-E are involved in modulating porcine oocyte maturation, fertilization and embryo development. Furthermore, SeMet and the combination of SeMet+Vit-E may be involved in reducing the accumulation of ammonia and subsequently in increasing the rates of maturation, fertilization, embryo development and the utilization of glucose in porcine embryos.

\section{References}

1. Tareq KMA, Miah AG, Salma U, Yoshida M, Tsujii H. Effect of amino acids and dipeptides on accumulation of ammonia in the medium during in vitro maturation and fertilization of porcine oocytes. Rep Med Biol 2007; 6: 165-170. [CrossRef]

2. Eagle H. Utilization of dipeptides by mammalian cells in tissue culture. Proc Soc Exp Biol Med 1955; 89: 96-99. [Medline]

3. Tareq KMA, Hossain MS, Akter QS, Sawada T, Afrose S, Hamano K, Tsujii H. Effect of amino acids and dipeptides on acrosome reaction and accumulation of ammonia in porcine spermatozoa. Rep Med Biol 2008; 7: 1223-1233.

4. Kosenko E, Kaminsky A, Valencia M, Lee L, Heraenegildo C, Felipo V. Superoxide production and antioxidant enzymes in ammonia intoxication in rats. Free Radic Res 1997; 
27: 637-644. [Medline] [CrossRef]

5. Sánchez-Gutiérrez M, García-Montalvo EA, Izquierdo-Vega JA, Del Razo LM. Effect of dietary selenium deficiency on the in vitro fertilizing ability of mice spermatozoa. Cell Biol Toxicol 2008; 24: 321-329. [Medline] [CrossRef]

6. Siegel RB, Murray FA, Julien WE, Moxon AL, Conrod HR. Effect of in vitro selenium supplementation on bovine sperm motility. Theriogenology 1980; 13: 357-367. [Medline] [CrossRef]

7. Nakamuro K, Okuno T, Hasegawa T. Metabolism of selenoamino acids and contribution of selenium methylation to their toxicity. J Heal Sci 2000; 46: 418-421. [CrossRef]

8. Palamanda JR, Kehrer JP. Involvement of vitamin E and protein thiols in the inhibition of microsomal lipid peroxidation by glutathione. Lipids 1993; 28: 427-431. [Medline] [CrossRef]

9. Tsujii H, Muranaka M, Hamano K. Culture of in vitro mouse embryos with vitamin $\mathrm{E}$ improves development. J Reprod Dev 2002; 48: 25-29. [CrossRef]

10. Olson SE, Seidel GE Jr. Culture of in vitro-produced bovine embryos with vitamin E improves development in vitro and after transfer to recipients. Biol Reprod 2000; 62: 248-252. [Medline] [CrossRef]

11. Tareq KMA, Akter QS, Takagi Y, Hamano K, Sawada T, Tsujii H. Effect of selenium and vitamin-E on acrosome reaction in porcine spermatozoa. Repro Med Biol 2010; 9: 73-81. [CrossRef]

12. Verma A, Kanwar KC. Effect of vitamin E on human sperm motility and lipid peroxidation in vitro. Asian J Androl 1999; 1: 151-154. [Medline]

13. Johnson LA, Aalbers JG, Grooten HJG. Artificial insemination of swine: fecundity of boar semen stored in Beltsville TS (BTS), modified Modena (MM), or MR-A and inseminated on one, three and four days after collection. Zuchthyg 1988; 23: 49-55. [CrossRef]

14. Petters RM, Reed ML. Addition of taurine or hypotaurine to culture medium improves development of one- and two-cell pig embryos in vitro. Theriogenology 1991; 35: 253. [CrossRef]

15. Hashem A, Hossein MS, Woo JY, Kim S, Kim JH, Lee SH, Koo OJ, Park SM, Lee EG, Kang SK, Lee BC. Effect of potassium simplex optimization medium and NCSU23 supplemented with beta-mercaptoethanol and amino acids of in vitro fertilized porcine embryos. J Reprod Dev 2006; 52: 591-599. [Medline] [CrossRef]

16. Hunter RHF, Polge C. Maturation of follicular oocytes in the pig after injection of human chorionic gonadotropin. J Reprod Fertil 1966; 12: 525-531. [Medline] [CrossRef]

17. Thouas GA, Korfiatis NA, French AJ, Jones GM, Trounson AO. Simplified technique for differential staining of inner cell mass and trophectoderm cells of mouse and bovine blastocysts. Reprod Biomed Online 2001; 3: 25-29. [Medline] [CrossRef]

18. Tsujii H, Lee JH, Hossain MS, Tareq KMA, Hamano K, Sawada T. The beneficial effect of fructose and glucose on in vitro maturation and the fertilization of porcine oocytes. Rep Med Biol 2009; 8: 19-24. [CrossRef]

19. Tareq KMA, Obata R, Miah AG, Hamano K, Tsujii H. Ammonia concentration in porcine ovarian developing follicles. J Mamm Ova Res 2005; 22: 185-189. [CrossRef]

20. Motulsky H. GraphPadPrisom Version 4.00 for Windows. GraphPad Sofware, San Diego California, USA, 2003: 176.

21. Nasr-Esfahani MH, Aitken JR, Johnson MH. Hydrogen peroxide levels in mouse oocytes and early cleavage stage embryos developed in vitro or in vivo. Development 1990; 109: 501-507. [Medline]

22. Demeestere I, Centner J, Gervy C, Englert Y, Delbaere A. Impact of various endocrine and paracrine factors on in vitro culture of preantral follicles in rodents. Reproduction 2005; 130: 147-156. [Medline] [CrossRef]

23. Murray AA, Swales AK, Smith RE, Molinek MD, Hillier SG, Spears N. Follicular growth and oocyte competence in the in vitro cultured mouse follicle: effects of gonadotrophins and steroids. Mol Hum Reprod 2008; 14: 75-83. [Medline] [CrossRef]

24. Goto Y, Noda Y, Mori T, Nakano M. Increased generation of reactive oxygen species in embryos cultured in vitro. Free Radic Biol Med 1993; 15: 69-75. [Medline] [CrossRef]

25. Agarwal A, Gupta S, Sikka S. The role of free radicals and antioxidants in reproduction. Curr Opin Obstet Gynecol 2006; 18: 325-332. [Medline] [CrossRef]

26. Chwa M, Atilano SR, Reddy V, Jordan N, Kim DW, Kenney MC. Increased stressinduced generation of reactive oxygen species and apoptosis in human keratoconus fibroblasts. Invest Ophthalmol Vis Sci 2006; 47: 1902-1910. [Medline] [CrossRef]

27. Sarafian TA, Bredesen DE. Is apoptosis mediated by reactive oxigen species? Free Radic Res 1994; 21: 1-8. [CrossRef]

28. Yang HW, Hwang KJ, Kwon HC, Kim HS, Choi KW, Oh KS. Detection of reactive oxygen species (ROS) and apoptosis in human fragmentated embryos. Hum Reprod 1998; 13: 998-1002. [Medline] [CrossRef]

29. Cetica PD, Pintos LN, Dalvit GC, Beconi MT. Antioxidant enzyme activity and oxidative stress in bovine oocyte in vitro maturation. IUBMB Life 2001; 51: 57-64. [Medline] [CrossRef]

30. Kodaman PH, Behrman HR. Endocrine-regulated and protein kinase C-dependent generation of superoxide by rat preovulatory follicles. Endocrinology 2001; 142: 687-693. [Medline] [CrossRef]

31. Combelles CM, Gupta S, Agarwal A. Could oxidative stress influence the in vitro matu- ration of oocytes? Reprod Biomed Online 2009; 18: 864-880. [Medline] [CrossRef]

32. Basini G, Tamanini C. Selenium stimulates estradiol production in bovine granulosa cells: possible involvement of nitric oxide. Domest Anim Endocrinol 2000; 18: 1-17. [Medline] [CrossRef]

33. Ip C. Lessons from basic research in selenium and cancer prevention. J Nutr 1998; 128 1845-1854. [Medline]

34. Ganther HE. Selenium metabolism, selenoproteins and mechanisms of cancer prevention: complexities with thioredoxinreductase. Carcinogenesis 1999; 20: 1657-1666. [Medline] [CrossRef]

35. Ip C, Ganther HE. Comparison of selenium and sulfur analogs in cancer prevention. Carcinogenesis 1992; 13: 1167-1170. [Medline] [CrossRef]

36. Jeong YW, Hossein MS, Bhandari DP, Kim YW, Kim JH, Park SW, Lee E, Park SM, Jeong YI, Lee JY, Kim S, Hwang WS. Effects of insulin-transferrin-selenium in defined and porcine follicular fluid supplemented IVM media on porcine IVF and SCNT embryo production. Anim Reprod Sci 2008; 106: 13-24. [Medline] [CrossRef]

37. Ichikawa T, Oeda T, Ohmori H, Schill WB. Reactive oxygen species influence the acrosome reaction but not acrosin activity in human spermatozoa. Int J Androl 1999; 22: 37-42. [Medline] [CrossRef]

38. O'Flaherty C, de Lamirande E, Gagnon C. Reactive oxygen species and protein kinases modulate the level of phospho-MEK-like proteins during human sperm capacitation. Biol Reprod 2005; 73: 94-105. [Medline] [CrossRef]

39. O'Flaherty C, Breininger E, Beorlegui N, Beconi MT. Acrosome reaction in bovine spermatozoa: role of reactive oxygen species and lactate dehydrogenase C4. Biochim Biophys Acta 2005; 1726: 96-101. [Medline] [CrossRef]

40. O'Flaherty C, de Lamirande E, Gagnon C. Reactive oxygen species modulate independent protein phosphorylation pathways during human sperm capacitation. Free Radic Biol Med 2006; 40: 1045-1055. [Medline] [CrossRef]

41. Agarwal A, Allamaneni SS. Role of free radicals in female reproductive diseases and assisted reproduction. Reprod Biomed Online 2004; 9: 338-347. [Medline] [CrossRef]

42. Fedeli D, Berrettini M, Gabryelak T, Falcioni G. The effect of some tannins on trout erythrocytes exposed to oxidative stress. Mutat Res 2004; 563: 89-96. [Medline]

43. Brzezińska-Ślebodzińska E, Slebodziński AB, Pietras B, Wieczorek G. Antioxidant effect of vitamin $\mathrm{E}$ and glutathione on lipid peroxidation in boar semen plasma. Biol Trace Elem Res 1995; 47: 69-74. [Medline] [CrossRef]

44. Marin-Guzman J, Mahan DC, Chung YK, Pate JL, Pope WF. Effects of dietary selenium and vitamin $\mathrm{E}$ on boar performance and tissue responses, semen quality, an subsequent fertilization rates in mature gilts. J Anim Sci 1997; 75: 2994-3003. [Medline]

45. Marin-Guzman J, Mahan DC, Whitmoyer R. Effect of dietary selenium and vitamin E on the ultrastructure and ATP concentration of boar spermatozoa, and the efficacy of added sodium selenite in extended semen on sperm motility. J Anim Sci 2000; 78: 1544-1550. [Medline]

46. Julien WE, Murray FA. Effect of selenium and selenium with vitamin E on in vitro mobility of bovine spermatozoa. J Anim Sci 1977; 45: 174-176.

47. Uhm SJ, Gupta MK, Yang JH, Lee SH, Lee HT. Selenium improves the developmental ability and reduces the apoptosis in porcine parthenotes. Mol Reprod Dev 2007; 74 1386-1394. [Medline] [CrossRef]

48. Ebert R, Ulmer M, Zeck S, Meissner-Weigl J, Schneider D, Stopper H, Schupp N, Kassem M, Jakob F. Selenium supplementation restores the antioxidative capacity and prevents cell damage in bone marrow stromal cells in vitro. Stem Cells 2006; 24 1226-1235. [Medline] [CrossRef]

49. Gopalakrishna R, Chen ZH, Gundimeda U. Selenocompounds induce a redox modulation of protein kinase $\mathrm{C}$ in the cell, compartmentally independent from cytosolic glutathione: its role in inhibition of tumor promotion. Arch Biochem Biophys 1997; 348: 37-48. [Medline] [CrossRef]

50. Yeo JE, Kang SK. Selenium effectively inhibits ROS-mediated apoptotic neural precursor cell death in vitro and in vivo in traumatic brain injury. Biochim Biophys Acta 2007 1772: 1199-1210. [Medline]

51. Gandhi AP, Lane M, Gardner DK, Krisher RL. Substrate utilization in porcine embryos cultured in NCSU23 and G1.2/G2.2 sequential culture media. Mol Reprod Dev 2001; 58: 269-275. [Medline] [CrossRef]

52. Petters RM, Wells KD. Culture of pig embryos. J Reprod Fertil Suppl 1993; 48: 61-73. [Medline]

53. Takahashi Y, First NL. In vitro development of bovine one-cell embryos: influence of lucose, lactate, pyruvate, amino acids and vitamins. Theriogenology 1992; 37: 963-978 [Medline] [CrossRef]

54. Iwata H, Akamatsu S, Minami N, Yamada M. Effects of antioxidants on the development of bovine IVM/IVF embryos in various concentrations of glucose. Theriogenology 1998; 50: 365-375. [Medline] [CrossRef]

55. Downs SM, Humpherson PG, Leese HJ. Meiotic induction in cumulus cell-enclosed mouse oocytes: involvement of the pentose phosphate pathway. Biol Reprod 1998; 58. 1084-1094. [Medline] [CrossRef]

56. Babior BM. Phagocytes and oxidative stress. Am J Med 2000; 109: 33-44. [Medline] 
[CrossRef]

57. Tammariello SP, Quinn MT, Estus S. NADPH oxidase contributes directly to oxidative stress and apoptosis in nerve growth factor-deprived sympathetic neurons. $J$ Neurosci 2000; 20: RC53. [Medline]

58. Guérin P, El Mouatassim S, Ménézo Y. Oxidative stress and protection against reactive oxygen species in the pre-implantation embryo and its surroundings. Hum Reprod 2001; 7: 175-189. [CrossRef]

59. Telford NA, Watson AJ, Schultz GA. Transition from maternal to embryonic control in early mammalian development: a comparison of several species. Mol Reprod Dev 1990; 26: 90-100. [Medline] [CrossRef]

60. Gardiner CS, Reed DJ. Status of glutathione during oxidant-induced oxidative stress in the preimplantation mouse embryo. Biol Reprod 1994; 51: 1307-1314. [Medline] [CrossRef]

61. Gardiner CS, Reed DJ. Synthesis of glutathione in the preimplantation mouse embryo.
Arch Biochem Biophys 1995; 318: 30-36. [Medline] [CrossRef]

62. Kim SC, Kim HW. Effects of nitrogenous components of urine on sperm motility: an in vitro study. Int J Androl 1998; 21: 29-33. [Medline] [CrossRef]

63. Keskes-Ammar L, Feki-Chakroun N, Rebai T, Sahnoun Z, Ghozzi H, Hammami S, Zghal K, Fki H, Damak J, Bahloul A. Sperm oxidative stress and the effect of an oral vitamin $\mathrm{E}$ and selenium supplement on semen quality in infertile men. Arch Androl 2003; 49: 83-94. [Medline] [CrossRef]

64. Kosenko E, Kaminsky Y, Lopata O, Muravyov N, Kaminsky A, Hermenegildo C, Felipo V. Nitroarginine, an inhibitor of nitric oxide synthase, prevents changes in superoxide radical and antioxidant enzymes induced by ammonia intoxication. Metab Brain Dis 1998; 13: 29-41. [Medline] [CrossRef]

65. Velvizhi S, Dakshayani KB, Subramanian P. Effects of alpha ketoglutarate on antioxidants and lipid peroxidation in rats treated with ammonium acetate. Nutrition 2002; 18: 747-750. [Medline] [CrossRef] 